\title{
Designing market-oriented production systems: theory and practice
}

\author{
Domien Draaijer and Harry Boer
}

A model is needed as a guide to conducting the manufacturing process effectively

The strategic role of manufacturing

Many companies' success in the marketplace depends on their ability not only to design, produce and deliver a wide range of low cost, high quality products rapidly and reliably but also to adopt and implement the technologies, management systems and forms of organization fitting to their situation. It is generally accepted now, both in academia and in industry, that these capabilities require organizations to formulate and implement consistent, strategy-driven decisions on manufacturing[1].

\section{State-of-the-art and theory of manufacturing strategy}

The aim of many publications on the subject has been first to help practitioners to withstand the increasing pressure on production, and second to encourage academia to investigate empirically the manufacturing strategy concept[2,3]. Whereas the former aim is gradually being achieved, empirical research into the way companies formulate and implement their manufacturing strategies and the effects of that process on success in the marketplace is relatively scarce. Consequently, although there are several useful concepts reported in the literature, a validated model that covers all the relevant insights managements need to conduct the manufacturing strategy process effectively is still lacking. The purpose of our research has been to make a step towards such a model. In this article we will present this model, discuss its background, in particular the prerequisites of a model to be useful for management, assess its validity using the results of 19 case studies, and indicate directions for further research needed to improve the utility of the model for management.
Prerequisites for a useful manufacturing strategy model

Models are an abstraction of the real life system we want to describe, analyse or whose performance we want to predict. The central problem of the present article concerns the formulation and implementation of a manufacturing strategy, in particular the description and analysis of production systems, and their (re-)design in the light of present and/or (anticipated) future market demands. In order for a model of production systems to be useful as a management tool for tackling this problem, the following, not necessarily sufficient, prerequisites must be met[4]:

- Completeness: the model should incorporate all intra- and extra-organizational elements and the relationships between these elements affecting success in the marketplace.

- Relevance: elements and/or relationships which do not to contribute to understanding the performance of a production system are irrelevant and should not be incorporated.

- Operationalization: all elements incorporated in the model need to be defined precisely, in order to make it possible to describe and analyse as exactly as possible the production systems studied and to predict their performance unambiguously.

The first step in the research was to find out whether such a model was readily available in the literature. We found several useful bits and pieces but no generic model covering all these prerequisites. As to the completeness requirement, there seems to be a convergence of opinions in the literature on the key items that need to be determined when a manufacturing strategy is being formulated. Skinner[5] for example, has mentioned five areas in which trade-off decisions must be made. Hayes

Part of the research here was funded by the Dutch Organization of Scientific Research (NWO). 
and W heelwright[1] have proposed eight categories. Four of these are structural in nature, the other four are infrastructural. These, and most other framew orks proposed in the literature, are basically structural in nature, indicating that consistent decisions must be made on the technologies and the organization of the production system. Hill[6] has taken a slightly different viewpoint by proposing a more functional framework which focuses on the required functioning of a production system in relation to the way the system qualifies for and wins orders in the marketplace. Table I summarizes relevant features of these framew orks, and relates them to the prerequisites formulated above, as follows. Three comments are appropriate.

First, all these frameworks comprise a classification of decision categories. However, most frameworks concentrate on manufacturing and operations management functions such as quality management and logistics. In view of the current wave of publications on concurrent engineering, however, surprisingly little attention is paid to the product and process design functions, to mention just one example of an extension needed to complete the frameworks found in the literature. The exception in this respect is Skinner[5], who has discerned product design/engineering as one of the areas that must be resolved. In addition, many frameworks are incomplete in the sense that they do not make a clear link between market demands and/or consequent performance indicators, and the design of the production system. The exception to this rule is Hill[6], who has incorporated performance indicators (qualifiers and order winners) in his framework. The question as to whether all decision categories are equally relevant and discriminate between success or failure in the marketplace is generally left unansw ered. This may be due to the relative lack of empirical testing of manufacturing strategy models, as concluded previously.

Empirical testing would be a problem in any case as, second, the frameworks found in the literature lack the operationalization needed to be able to test a framework in practice. Consequently, the relationships between the decision categories remain unclear, and the question as to how design choices for one category affect those made for other categories cannot be answered adequately. Hill's[6] framework is an interesting exception in that it is an operational model to the extent that it describes in considerable detail the choices to be made with regard to several, but not all, functions that must be performed in order for the production system to operate effectively. However, managerial implications of that, in terms of the technologies and organizational arrangements needed for the system to function effectively, are lacking.

Third, many authors have contended that consistent decision making is the main prerequisite for effectiveness, i.e. success in the marketplace. A ccording to Hayes and W heelwright[1], for example, the strategy must display:

Table I. Comparison between frameworks proposed in literature

\begin{tabular}{|c|c|c|c|c|c|c|c|}
\hline & & & & Completeness an & Ianc & & \\
\hline & & Type of & Organizational & Environmental & & nsIst & \\
\hline Authc & & framework & elements & elements & 1 & 2 & 3 \\
\hline Wood & $\operatorname{ard}[7]$ & structural & + & - & - & - & - \\
\hline Hayes & ind W heelwright[1] & structural & 0 & 0 & 0 & 0 & 0 \\
\hline Skinn & & structural & 0 & 0 & + & + & 0 \\
\hline Hill[6 & & functional & + & 0 & + & 0 & 0 \\
\hline Bolwi & et al.[8] & structural & 0 & 0 & 0 & + & + \\
\hline Krabb & ndam[9] & structural & + & - & + & 0 & 0 \\
\hline Kotha & nd Orne[10] & functional & 0 & 0 & 0 & + & 0 \\
\hline $\begin{array}{l}\text { Intent } \\
\text { propo }\end{array}$ & $\begin{array}{l}\text { nof framework } \\
\text { ed in this article }\end{array}$ & structural & + & + & + & + & + \\
\hline Key: & $\begin{array}{l}1=\text { comparison be } \\
2=\text { comparison be } \\
3=\text { comparison be } \\
+=\text { mentioned anc } \\
0=\text { mentioned but } \\
-=\text { not mentioned }\end{array}$ & $\begin{array}{l}\text { ties and requi } \\
\text { ate and manuf } \\
\text { lal goals } \\
\text { an instrument } \\
\text { on an instrum }\end{array}$ & & & & & \\
\hline
\end{tabular}


(1) internal consistency, i.e. within the manufacturing function and across functions in the company; and

(2) external consistency, i.e. between the manufacturing function and the environment of the company in order for the manufacturing strategy to augment the competitiveness of the company and to contribute to the competitive advantage pursued.

Similar consistency criteria can be found in other manufacturing strategy publications[5] and also in the organization theory literature[11]. So, there seems to be a convergence of opinions on consistency being a necessary and possibly even sufficient condition for a company to be effective. However, insights into the relationship between the design of a production system and its contribution to the company's performance in the marketplace are at best underdeveloped. A gain, lack of operationalization and testing of the models proposed seems to explain this.

So, we had to conclude that none of these widely cited frameworks suited our purposes entirely, and the second step in the research was the development and operationalization of a more suitable model, combining the strengths of the frameworks described above and adding to that other relevant manufacturing strategy and organization theories. This model will be described in the next section. The third step was to use the model to describe and analyse 19 operational production systems, in order to find out whether it is possible to use the model to explain the extent to which these systems perform effectively. Based on the results of that step, one of the main conclusions, described in much more detail in a subsequent section, will be that the model is not perfect as yet, but worth the effort to pursue the final step towards validation of the model as a management tool. This step involves the application of the model in the actual redesign of existing production systems, adapting them to changing market demands, or in the design of entirely new production systems for existing or new market segments. The evaluation of the extent to which those systems operate according to expectations will determine the value of the model or, at least, provide insight into improvements to be made. This step has still to be made and cannot therefore be reported in the present article.

\section{A model of production systems: concept and operationalization}

Production systems can be described along the following lines, presented in more detail in Boer and K rabbendam[12] (see Figure 1 for an illustration of the model).

\section{Model}

Organizations are purposive systems of people who, using multiple technologies, transform inputs into outputs. Organizations need technologies to transform inputs into outputs[13]. Combining three basic elements found in widely referenced publications on the subject, namely Woodward[7], T hompson[13] and Perrow [14], technology can be defined as the types and patterns of activity, equipment and material, and knowledge and experience used to perform transformations. A s such, technology is the knowledge incorporated in the people, resources and processes of the organization. A s to the latter, three different processes can be distinguished. The purpose of the primary processes is to transform informational (including customer demands!) and material inputs into informational (e.g. services, software, manuals, instructions) and/or material outputs (i.e. physical products) that conform to demands. In order to reduce the complexity of the research, we focused on manufacturing and assembly. Other primary processes are product and process design (including process planning and production planning), distribution, purchasing and sales. Strategic and adaptive control processes are aimed at adapting the organization to changes in its environment and vice versa. The aim of operational control processes, such as shopfloor control and quality control, is to monitor the primary processes and to resolve any disturbances encountered. Finally, the company needs to perform a range of maintenance processes, aimed at ensuring the availability of qualitatively and quantitatively sufficient people and technologies. The present research has focused on machine tool maintenance and the technologies to perform this process.

Organizations need to structure themselves to operate effectively. A key prerequisite of a model to be useful for management therefore is that it provides insight into the so-called organizational arrangements that organizations use to divide and co-ordinate their activities. Formal arrangements constituting the structure of the organization are job specialization, behaviour formalization, unit grouping, and lateral linkages (see[11]). Organizational culture refers to the informal arrangements and is based on the key values, beliefs, understandings and norms shared by members of an organization[15].

Organizations are open systems. In order to survive, an organization must manage its relationships with the environment adequately. Important elements in the context of the present research are: customers, suppliers and competitors[16]. Customers provide an important informational input, namely product specifications. A great deal of the company's success depends on the extent to which it is able to respond adequately to customer demands. These demands are not unlimited. Their ultimate strength depends on what industry has to offer or, in other words, the performance of the company and its competitors. Finally, another important element are suppliers of critical resources, in particular raw materials and parts, and of technologies. Organizations need technologies to perform their processes, and 
Figure 1. A contingency model of organization

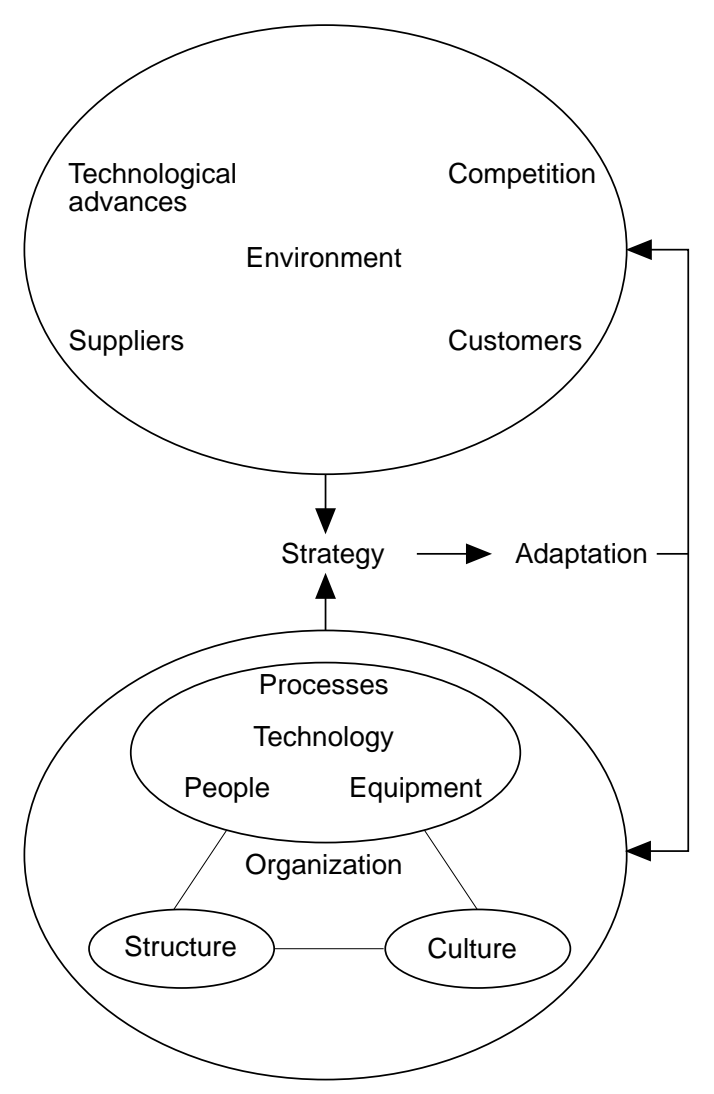

technological advances may create new opportunities for organizations to produce their products or to manage their operations more effectively. Organizations that are not able to adopt, implement and operate new technologies effectively will eventually lose the competitive battle.

\section{Operationalization}

The next step in the research was to operationalize the model. We shall not dwell on the method and literature used to perform this step. The details of this are described in Draaijer[17]. The result is depicted in Figure 2 and Tables II, III and IV. The shaded areas concern the characteristics of one of the sample companies, which is described in the next section to illustrate how the framew ork was used in the research. The core of the framework, Table IV, is a so-called morphological representation, which is a means to describe and classify the form or structure and the fundamental characteristics of a certain phenomenon[18]. A well-known example of such a model is Hill's[6] framework, on which the initial idea underlying the present morphological representation was based. A ccording to Zwicky[18] "the morphological way of looking can be used for all transferable knowledge about aspects of the internal and external world, i.e. aspects on which people speculate" (translation by the authors). Major advantages of morphological representations are that they reduce the chance of forgetting essential items and improve the communication between people and reduce misunderstanding, which are important advantages considering the complaint that production managers lack the language needed to explain their function clearly and effectively to others in the organization[6]. Furthermore, they enable the researcher to gain quick insight into a certain phenomenon[19], in this case the design and performance of a production system, and to systematize the findings regarding that phenomenon (see [20]). T he next section presents an example of the way the framew ork was used to describe the 19 cases studied for the present research. In the subsequent section, the main results found from the analysis of these cases are described.

A sample case study: the television set producer General information about the organization and its products

The plant, employing approximately 2,500 people, is one of the production sites of a consumer electronics company. Its main activity concerns the assembly of two different products, namely projection and direct television sets. The bills-of-materials of these products amount to 12 and three layers respectively. The plant's main goal is to survive in a very competitive environment. The plant has organized itself into the following departments: projection television, direct television, manufacturing engineering, quality, and materials management.

Since 1985 major changes have taken place. The functional layout, in which the transport batches were the same size as the manufacturing batches, was replaced by product-oriented flow-lines with lot size one carriers. A nother major change was the reduction of the number of suppliers by almost 20 per cent.

Primary transformation processes

The primary processes are depicted in Figure 2.

The environment

The characteristics of the company's environment are summarized in Table II, which shows the hostility of a fairly dynamic environment.

Figure 2. The primary process of the television set producer

Engineering Purchasing $\longrightarrow$ Costing


Table II. Environmental characteristics

Environment

Diversity

\begin{tabular}{|c|c|c|c|c|c|c|}
\hline Number of competitors & 0 & $1-5$ & $6-10$ & $11-20$ & $21-30$ & $2>30$ \\
\hline Number of suppliers & $\leq 10$ & $11-25$ & $26-50$ & $51-100$ & & $>250$ \\
\hline Number of customers & $\leq 50$ & $50-100$ & $100-200$ & $201-400$ & $401-800$ & $>800$ \\
\hline Stability & high & & & & & low \\
\hline Complexity & low & & & & & high \\
\hline Hostility & low & & & & & high \\
\hline
\end{tabular}

Table III. The television set producer's performance relative to competition

\begin{tabular}{|c|c|c|c|c|}
\hline Performance profile relative to competitors & 4 & 3 & 2 & 1 \\
\hline Costs/price & $(+)$ & & & \\
\hline Product quality & $(0)$ & & & \\
\hline Process reliability & (0) & & & \\
\hline Delivery time & & $(+)$ & & \\
\hline Delivery reliability & & $(+)$ & & \\
\hline Product range & & (0) & & \\
\hline Product flexibility & & & (0) & \\
\hline Innovativeness & & $(+)$ & & \\
\hline Volume flexibility & $(+)$ & & & \\
\hline Key: & & & & \\
\hline
\end{tabular}

Performance profile

High customer demands further illustrate the role of the environment and the present and desired performance required from the organization.

The manufacturing system

The plant is organized in two flow-lines and six focused cells. The range of products assembled at each line is about 50-60 models. Batch sizes are smaller than 500 pieces. Work-in-progress is transported using a limited number of pallets. M anufacturing lead time is between two and four hours. Every flow-line consists of 170 operators, four group leaders, a production engineer, a quality auditor, a quality control engineer and a flow-line manager.
Recent and planned changes

Over the past 4-5 years, a number of changes have been made. A mong others, interdisciplinary engineering was introduced, involving new product development by a team of product planners, manufacturing engineers, and a representative of purchasing. This change, aimed at "slashing down the ivory tower of product development at headquarters", resulted in a much simpler and more modular product (three chassis instead of 13) with the possibility of making it customer specific at a much later stage of production than previously (Table IV, arrow 1).

A single sourcing policy resulted in the number of suppliers decreasing from 215 to 180 (Table II, arrow 2) and at present 93 per cent of the parts are from one 
Table IV. A morphological representation of the television set producer's production system

$\begin{array}{ll}\text { Parameter Characteristics } & \text { Chat }\end{array}$

Input

Type

Number of material codes

Design characteristics

Number of components

M anufacturing processes

Number of processes

Equipment

Material flow

Layout

Transportation method

Operator's task

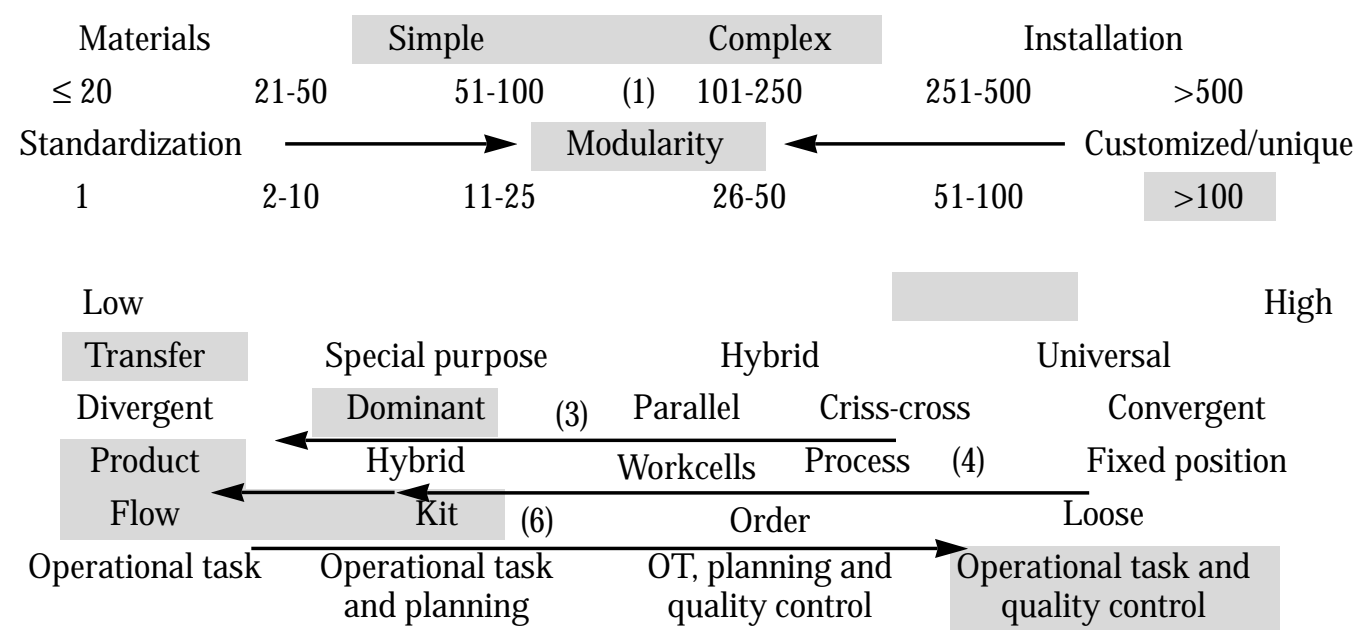

Control processes

Customer order decoupling point

(CODP)

Planning principle

Planning technique

Quality control principle

Maintenance principle

Organizational arrangements

Horizontal specialization

Vertical specialization

Formalization

Unit grouping

Liaisons

Output

Volume ( $\left.{ }^{30} \mathrm{log}\right)$

Number of product codes

\section{6}

$\leq 20$
Produce-to-stock

Stock-oriented

BSC

QI

Time-based

Low

High

High

Product
None

A ssemble-to-order Programme-oriented

OPT

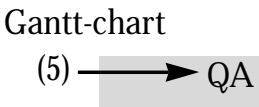

(5) $\longrightarrow$ QA

$T Q C$

Condition-based

$1 / 2$

$\mathrm{QC}$

Engineer-to-order

Order-oriented

Network

TQM

Breakdown-based

Key OT = operational task; $\mathrm{QC}=$ quality control; $\mathrm{BSC}=$ base stock control; $\mathrm{OPT}=$ optimized production technology; $\mathrm{MRP} 1 / 2=$ material requirements planning/manufacturing resources planning; $\mathrm{QI}=$ quality inspection; $\mathrm{QA}=$ quality assurance; $\mathrm{T} \mathrm{QC}=$ total quality control; $\mathrm{TQM}=$ total quality management; $\mathrm{TBM}=$ time-based maintenance; $\mathrm{CBM}=$ condition-based maintenance; $\mathrm{BDM}=$ break-down maintenance

supplier. Together with barcoding identification of 90 per cent of incoming components, and a 100 per cent barcoding of PCBs, this resulted in an increase of inventory accuracy from 60-75 per cent to 98 per cent.

The process-oriented layout was replaced by a productoriented layout (Table IV, arrow 3). The automatic insertion equipment was moved to the front end of the chassis line, and that line was linked to the assembly line. On top of that, surface-mounting technology was introduced. This adjustment changed batch transportation in flow transportation, and made kitformation possible in final assembly (Table IV, arrow 4). Formerly, quality inspection was only conducted during final testing. Today there are quality checks after and during automatic insertion, chassis-building and 
assembly (Table IV, arrow 5). The test and alignment phases are almost fully automated, which has reduced final inspection costs by nearly 80 per cent. The tasks of the quality department were reduced considerably and all personnel with quality tasks were assigned to the flowlines (Table IV, arrow 6).

The above also caused a lot of changes in the organizational arrangements. At present, instead of several functional managers, one manager is responsible for each flow-line. Functional barriers within the plant have been broken down, which has resulted in group leaders for each process reporting to the flow-line manager.

A nother change took place within the set and relative priorities of performance criteria. Labour and equipment efficiency were replaced by market-oriented performance criteria, in descending order of importance:

(1) on-time delivery;

(2) short order lead time; and

(3) high flexibility.

The overall results were reductions of:

(1) inventory levels by 80 per cent;

(2) lead time from 15 days to 2-4 hours;

(3) set-up time from four hours to less than 1 minute; and

(4) buffers between automatic insertion and chassis, and between chassis and final assembly, from 15 days and four days respectively, to zero.

The company is still in the process of implementing ISO 9000. Furthermore, EDI-links with suppliers and (main) customers are implemented in order to reduce further inventory and lead times.

\section{Results}

In this section the main findings of the research are presented, starting with a discussion of the framework along the criteria formulated before, in due order: completeness of the framework, relevance and operationalization of elements. Next, considerable attention is paid to the consistency concept and the relationships between consistency and performance in the marketplace. Finally, implications for management are indicated. In the concluding section, the utility of the framew ork is discussed, and directions for further research, indicated throughout the present section, are summarized.

Completeness, relevance and operationalization of the framework

Completeness

Most, but not all, of the observations made in the case studies can be explained using the framew ork as a basis for discussion (see Draaijer[17] for much more detail). A t the same time, how ever, we are sure that the framew ork is not as yet complete. A s indicated in a previous section, we decided not to study product and process engineering in detail. M ost cases reinforced the need to incorporate these processes in the framework. For example: the refrigerator plant and the turbine and compressor plant:

In the refrigerator plant, the product and process design functions had co-operated recently, to reorganize the plant, involving a shift from a functional layout to cellular manufacture integration of operations, based on group technology; the implementation of an FMS; and redesign of products aimed at reducing the number of components. In effect, cost effectiveness and delivery reliability increased, and lead time and number of defects were reduced. The effort did not result, however, in any increase in market share, as the main competitors took similar measures. The company did not lose market share, either.

A nother example concerns the compressor and turbine company which had a lead time problem. It appeared that product engineering caused about 75 per cent of order lead time, mainly due to frequent and poorly managed exchange of specifications and drawings with customers, and lack of communication with the plant, in particular production engineering which was located in another building. The company tackled this problem by relocating the product engineers, which resulted in a much improved communication between the two functions, and by improving the interaction with customers. As a result, product engineering now takes 50 per cent of order lead time. Somewhat surprisingly the company did not make the next, rather obvious, step towards further reduction of engineering lead time, by introducing concurrent engineering. Rather, a lot of effort was put into reducing manufacturing lead time, by reorganizing the plant through replacing the present functional layout by a cellular layout.

Further research is needed to determine the role of the technologies used in these processes, the way they are organized, and technological and organizational linkages with other processes. The same applies for the role, technologies and organization of the purchasing, sales and distribution functions which are responsible for acquiring inputs and customer orders, and getting finished products to customers, which also needs further investigation. Finally, we did not pay much attention to organizational culture, a dimension that appeared to play an important role in one or two cases. For example, the bicycle factory has put a lot of effort into changing its culture, to make it a much more open one, in which informal communication and participation are encouraged, and employees are engaged in finding opportunities for the continuous improvement needed for the company to stay ahead of competition.

\section{Relevance and operationalization}

As to the relevance of the framework, on a case-by-case basis, some dimensions seem to be more relevant than are others. On an overall level, however, we found no indication that any of the dimensions are irrelevant. Further research into a wider sample of companies and 
using a framew ork that is more complete, as indicated above, is needed to determine the relevance of the dimensions specified.

The more detailed operationalization, compared with other frameworks proposed in the literature, enabled us to reveal more cause-and-effect chains, and to discusss the next issue, the role of consistency, in much more detail.

\section{Consistency}

External consistency

All companies involved in the research are externally consistent. They are capable of serving their markets adequately, that is, according to customer demands. Furthermore, they are continually implementing action plans in response to changes in market demands or in an attempt to improve their position relative to competition, as illustrated throughout this section. The most important finding perhaps is that our data strongly suggest that external consistency is a much more important factor affecting organizational effectiveness than is internal consistency.

\section{Internal consistency}

Internal consistency, i.e. the extent to which the elements of the organization fit to one another, is generally considered to be a major prerequisite for a company to be able to meet market demands. How ever, contrary to what we expected, market demand does not seem to exert much influence on the way otherwise successful companies design their production systems. Although it appeared to be possible to cluster the companies, as depicted in Figure 3, the dimensions explaining similarity of production systems are not similarities in market demands to be met, but:

- resource complexity: the degree to which the resources can be understood easily, which relates to the number and variety of processes that are needed to perform the transformation; the degree of coupling of the processes; and the sophistication, regulation and reliability of the machines used for the transformation;

- product complexity: the extent to which products can be classified as simple or composed, which relates to the variety and number of parts composing the products; product variety; volume per product; and the analysability of customer demand.

Together these complexities explain an overriding construct, namely: control complexity - the extent to which control activities can be characterized as easy or difficult; based on both resource and product complexity, this dimension relates to the information and knowledge needed to perform the control task; the diversity of and interdependence between pieces of information; and the number of information sources.

Figure 3. Clustering of cases according to product, process and control complexity

\begin{tabular}{|c|c|c|c|c|}
\hline & \multicolumn{3}{|c|}{ Product complexity } & \\
\hline & Low & Moderate & High & \\
\hline \multirow{3}{*}{$\begin{array}{l}\text { Resource } \\
\qquad \text { Moderate } \\
\text { Complexity }\end{array}$} & $\begin{array}{l}\text { Bottles } \\
\text { Tin cans } \\
\text { Paper }\end{array}$ & \begin{tabular}{|ll}
$(1.2)$ & \\
& Tubes \\
& Castings \\
& Production parts
\end{tabular} & (1.3) & \multirow{3}{*}{$\begin{array}{l}\text { Low } \\
\text { Control } \\
\text { Moderate } \\
\text { Complexity }\end{array}$} \\
\hline & $\begin{array}{l}\text { (2.1) } \\
\text { Springs } \\
\text { Sheet metal } \\
\text { Glass/wood } \\
\text { concrete }\end{array}$ & $\begin{array}{ll}(2.2) & \\
& \text { Mattresses } \\
& \text { Shaving units }\end{array}$ & $\begin{array}{l}\text { (2.3) } \\
\text { Television sets } \\
\text { Bicycles } \\
\text { Lawn mowers }\end{array}$ & \\
\hline & (3.1) & $\left(\begin{array}{ll}(3.2) & \\
& \text { Combustion/valves } \\
& \text { Detection systems }\end{array}\right.$ & $\begin{array}{l}\text { (3.3) } \\
\text { Refrigerators } \\
\text { Fixtures and special } \\
\text { machines } \\
\text { Turbines and } \\
\text { compressors }\end{array}$ & \\
\hline High & Low & $\begin{array}{c}\text { Moderate } \\
\text { Control complexity }\end{array}$ & High & \\
\hline
\end{tabular}


The companies within one cell do not differ very much, whereas there are major differences between the clusters. For example, common characteristics of cell 1.1 companies, such as the tin can company are: relatively few suppliers and few or average number of customers; a stable and simple environment; standard products produced in high volumes but consisting of just a few components; a product-oriented transfer line with special purpose machinery; production-to-stock; high horizontal and vertical specialization and high to moderate levels of formalization. Cell 3.3 companies, such as the fixtures and special machines company, are different in many respects. These companies have many more suppliers. Their customers require low volumes of complex, customized products that consist of several hundreds of components. Their environment is highly dynamic and moderately complex. Universal equipment, laid out functionally, is used to produce-to-order. Formalization is moderate, and levels of vertical and horizontal specialization are moderate to high. So, it seems that the different cells represent different production systems. However, contrary to what we had expected, market demands do not explain the design of a production system, as Figure 4 shows.

This analysis shows that companies that have organized their production systems very differently are still able to meet similar market demands, whereas companies that have similar production systems are capable of meeting very different sets of market demands. For example, both the paper company and the detection system company are innovative companies, capable of achieving high levels of product quality, process quality, and volume flexibility. The tin can company and the fixtures and special machinery company are similar to the extent that both companies perform well in terms of product price, process quality, delivery time and delivery reliability. Yet, each pairing involves two entirely different production systems: the paper and tin can producers are cell 1.1 companies, the detection system and fixtures and special machinery companies represent cell 3.3. M ore generally speaking, the tin can, shaving unit, mattresses, tubes, castings, combustion/valves, and fixtures and special equipment companies have different production systems, representing cells 1.1, 1.2, 2.2 and 3.3, and are still capable of meeting similar demands of product quality, process reliability, delivery time and reliability, and volume flexibility.

The industrial refrigerator company and the professional lawn mower company are illustrations of the other observation. Both companies are in cell 3.2. But, whereas the former needs to perform well in terms of costs, process reliability, delivery time and delivery reliability, the latter has to meet an entirely different set of customer demands, namely product costs, quality, flexibility, and volume flexibility. So, apparently, very similar production systems are capable of meeting very different sets of market demands.

Figure 4. Clustering of cases, according to market demands

\begin{tabular}{|c|c|c|c|c|}
\hline $\begin{array}{l}\text { Product quality } \\
\text { Delivery time } \\
\text { Innovativeness } \\
\text { Volume flexibility }\end{array}$ & $\begin{array}{c}\text { Costs/price } \\
\text { Process reliability } \\
\text { Delivery time } \\
\text { Delivery reliability }\end{array}$ & $\begin{array}{l}\text { Product quality } \\
\text { Process reliability } \\
\text { Delivery time } \\
\text { Delivery reliability } \\
\text { Product change } \\
\text { Volume flexibility }\end{array}$ & $\begin{array}{l}\text { Product quality } \\
\text { Process reliability } \\
\text { Delivery reliability } \\
\text { Product range }\end{array}$ & $\begin{array}{c}\text { Costs/price } \\
\text { Product quality } \\
\text { Product flexibility } \\
\text { Volume flexibility }\end{array}$ \\
\hline $\begin{array}{c}(1.1) \\
\text { Paper } \\
(2.1) \\
\text { Sheet metal } \\
(3.2) \\
\text { Detection systems }\end{array}$ & $\begin{array}{c}(1.1) \\
\text { Bottles } \\
(1.2) \\
\text { Production parts } \\
(2.3) \\
\text { Bicycles } \\
\text { (3.3) } \\
\text { Refrigerators }\end{array}$ & $\begin{array}{c}(1.1) \\
\text { Tin cans } \\
(1.2) \\
\text { Tubes } \\
\text { Castings } \\
(2.2) \\
\text { Mattresses } \\
\text { Shaving units } \\
(3.2) \\
\text { Combustion/valves } \\
(3.3) \\
\text { Fixtures and special } \\
\text { machines }\end{array}$ & $\begin{array}{c}\text { (2.1) } \\
\text { Springs } \\
(3.3) \\
\text { Turbines and } \\
\text { compressors }\end{array}$ & $\begin{array}{c}(2.1) \\
\text { Glass/wood concrete } \\
(2.3) \\
\text { Television sets } \\
\text { Lawn mowers }\end{array}$ \\
\hline
\end{tabular}


There are two factors explaining this phenomenon. First, market demands such as delivery time, and also product price, are absolute dimensions. The delivery time accepted by customers of the tin can factory is in the order of one or two days, whereas the customers of the fixtures and special machinery company accept delivery times in the order of several months. This explains many of the differences between the two companies, but not all, because of the nature of process reliability and delivery reliability. Both are relative parameters in that they can be expressed in a percentage of products delivered according to specifications and at the negotiated time respectively. We would expect similar levels of these criteria to lead to similar production systems. This appears not to be the case.

So, we cannot but conclude that there is some truth in the second explanation, namely that the internal consistency hypothesis needs further investigation. Our data leave the question unanswered as to whether the configurations identified are internally consistent or not. W hat the research does show, however, is that, contrary to communis opinio in organization and manufacturing strategy theory, there is no one-to-one relationship between the design of a production system and the performance of that system in the marketplace. Rather, companies seem to have and take considerable space in designing their production systems, as observed earlier by Bessant and Grunt[21]. Further research is needed not only to sustain this conclusion but also to identify the range within which companies are relatively free to select their technologies and organizational arrangements in order still to perform effectively.

It could well be that the width of the boundaries differs between industries, with some industries allowing for a lot of, at first sight internally inconsistent, one-eyes ruling the blind, whereas in other industries internally inconsistent companies fail to qualify for the marketplace. Perhaps the companies involved in the present research are representatives of the first category, whereas the latter type could be those that have to meet all requirements incorporated in the sand cone model proposed by Ferdows and De Meyer[22]. This model depicts four generic manufacturing capabilities as a sand cone of layers, one on top of the other so as to represent the cumulative effect that can be expected from developing these capabilities in the sequence of quality as the bottom layer, with dependability as the next layer, flexibility the third layer and, fourth, on top of all that, cost effectiveness. Our hypothesis is that, if this model is correct, companies competing on price have to pay close attention to quality, dependability and flexibility, as well as the efficiency of operations, which should considerably limit the space these companies have to design their production system. A gain, further research is needed either to confirm or to reject this hypothesis.
Implications for management

$M$ any lessons can be draw $n$ from the present research. The most interesting ones are presented here. First of all, external consistency is the most important goal for a company to pursue, but it seems that many companies use considerable space for designing a production system fitting appropriately to customer needs. Furthermore, as many of our sample companies experienced, the redesign of a production system may well lead to improved customer responsiveness, but not necessarily to a bigger market share, as competitors do not tend to sit still either. The only way towards achieving competitive edge, irrespective of how the design configuration eventually looks, is ongoing strategy-driven improvement. This requires management to monitor and assess continuously the impact of developments in market demand and competition, technologies and organizational concepts, both in the company's own industry, and other industries. Ongoing improvement also requires a continuous cycle of formulating a corporate objectives-driven market strategy, identifying the way the company may not only qualify for that market but also win orders, and select appropriate technologies and organizational arrangements supporting the market strategy (see Hill[6]). In doing so, management should realize that adaptations, whether new technologies or new organizational arrangements are concerned, should always be made on the basis of their contribution to the business[6] rather than their "technical" specifications. Furthermore, technological change hardly ever automatically leads to improved performance. It should always be combined with (other technological and) organizational changes.

Reduction of the process and product complexity, through a more product-oriented or cellular layout and standardization/modularization of product designs, yields many benefits, in particular reduced complexity of and effort to be put into shopfloor control. How ever, reduction of complexity may require a wide range of additional adaptations, in particular if the production system moves from one cell in Figure 3 to another, as each cell represents a basically different production system. The television set manufacturer provides an example of this. Reduction of complexity resulted in a shift from cell 3.3 to cell 2.3 , and required many additional adaptations, as described in the previous section.

Effective manufacturing strategy decision making requires that clear, market-related objectives are set and that the effects that changes have on performance are evaluated. This is difficult enough. Somewhat surprisingly, considering that for only a minority of companies (in our sample, only four of the 19 cases) costs are a major performance indicator, cost effectiveness, and related indicators such as productivity, still seem to bethe only criteria for measuring performance in many companies. Performance measurement systems, other than those measuring factors such as efficiency and 
productivity, are at best underdeveloped. In view of what is happening in many industries, in particular the everchanging relative importance of different market demands, much more effort should be put into developing and maintaining tools capable of assessing a much wider span of factors, and feeding these tools with information.

The framework proposed in the present article is a powerful tool for conducting the above activities and for using as a basis for developing better instruments for evaluating the present performance of a production system, and assessing the impacts of environmental changes taking place. This brings us to the final issue, the utility of the framework.

\section{Conclusion}

The utility of the framework

The framework presented in this article appears to be a powerful research tool. It provides the possibility for describing and analysing a production system accurately and explaining its performance in the marketplace. Furthermore, the framework can be completed in one or two days of field research, so it can be used to build up rapidly a much wider sample of cases than the 19 studied hitherto, which is a useful feature in respect of the validation of the framework. Contrary to other frameworks in the literature, it has been operationalized structurally, linking inputs, technologies, outputs, organizational arrangements and environmental characteristics, including market demands. Further validation is needed though, to the extent previously discussed, in particular to develop it into a framework with which the performance of production systems can be predicted accurately. This will be an ongoing effort as market demands, technologies and organization theories are ever-changing.

In spite of that, we think that the framework is a powerful management tool as well. It is useful as an instrument for "benchmarking", providing the capability of comparing a production system's design and performance with that of competitors' systems or even solutions for essentially similar problems found in other industries. Furthermore, the framew ork provides a means of communication, an important feature considering that "production managers do not have a history of explaining their function clearly and effectively to others in the organization", which "is particularly the case in terms of the manufacturing strategy issues that need to be considered and the production consequences that will arise from the corporate decisions under discussion"[6]. Completing the framework "simply" requires management to consider market demands, competitive position, business implications of production, control and maintenance technologies, and organizational arrangements, all of which are key items while manufacturing strategy decision are being made.

\section{Further research}

The objective of the present article was to present a framew ork suitable for the description, analysis and, if necessary, (re-)design of manufacturing systems, to make them fit better to present and/or future market demands. Important prerequisites of such a framew ork to be a valid tool for designing market-oriented production systems are that it should incorporate a complete set of relevant and operationalized elements and relationships explaining the system's performance. The results discussed in the previous section showed that the present framework is neither complete, nor yet proven in validity. On the other hand, the above discussion also indicates that the framew ork is a step in the right direction.

Several directions for further research were indicated in the article. We will not summarize them here, but refer to two key areas. First, there are still many questions as to the internal consistency concept. Our research has suggested that companies have considerable capacity for designing their production systems, and different systems are capable of meeting highly similar market demands. Further research of companies active in similar product-market combinations, and across industries, is needed to increase insight into this concept and to find out whether internal consistency is a prerequisite for a company's success in the marketplace, and to what extent in terms of the width of the design space.

Second, the discussion above has suggested that it is as yet impossible to point out exactly and unambiguously how an organization should design its manufacturing system in order to perform successfully in the marketplace. Further research is needed to validate the framework. This requires that it is made more complete, the relevance of the elements and relationships are assessed, and perhaps even the operationalizations of one or two elements are reconsidered. Then, ideally, the framework can be used in the actual (re-)design of production systems. The quality of the predictions made using the model will determine whether it is a useful management tool for designing market-oriented production systems.

\section{Note and references}

1. Hayes, R.H. and Wheelwright, S.G., Restoring Our Competitive Edge, John Wiley \& Sons, New York, NY, 1984.

2. Flynn, B.B., Sakakibare, S., Schroeder, R.G., Bates, K.A. and Flynn, E.J., "Empirical research methods in operations management", Lournal of Operations Management, Vol. 9 No. 2, 1990, pp. 250-84.

3. Swamidass, P.M., "E mpirical science: new frontier in operations management research", Academv of Management Review, Vol. 16 No. 4, 1991, pp. 793-814. 
4. De Leeuw, A.C.J., E en Boekje over Bedrijfskundige M ethodologie (A Booklet on Research M ethodology), Van Gorcum, A ssen, 1990.

5. Skinner, W., M anufacturing: the Formidable Competitive Weapon, John Wiley \& Sons, New York, NY, 1985.

6. Hill, T., Manufacturing Strategy, Macmillan, Basingstoke, 1985.

7. Woodward, J., Industrial Organization: Theory and Practice, Oxford University Press, London, 1965.

8. Bolwijn, P.T., Boorsma, J., van Brenkelen, Q.H., Brinkman, S. and Kumpe, T., Flexible M anufacturing: Integrating Technical and Social Innovation, Elsevier Science Publishers, A msterdam, 1986.

9. Krabbendam, J.J., "New technologies and organizational adaptations", PhD thesis, School of M anagement Studies, University of Twente, Enschede, 1988 (in Dutch).

10. Kotha, S. and Orne, D., "Generic manufacturing strategies: a conceptual synthesis", Strateqic Management lournal, Vol. 10, 1989, pp. 211-31.

11. Mintzberg, H., The Structuring of Organizations, Prentice-Hall, New York, NY, 1979.

12. Boer, H. and Krabbendam, J.J., "Organizing for marketoriented manufacture", paper presented at the POMS Conference, New York City, NY, 18-20 November, 1991.

13. Thompson, J.D., Organizations in Action, M cGraw-Hill, New York, NY, 1967.
14. Perrow, C., "A framework for the comparative analysis of organizations", A merican Sociological Review, Vol. 32 No. 2, 1967, pp. 194-208.

15. Daft, R.L., Organization Theory and Design, West Publishing Company, St Paul, M N, 1992.

16. See Daft[15] for a more complete description of an organization's environment.

17. Draaijer, D.J., "Market-oriented manufacturing systems: theory and practice", PhD thesis, University of Twente, Enschede, 1993.

18. Zwicky, F., Entdecken, Erfinden, Forschen im M orphologischen Weltbild, (Discover, Experience and Forecast by M eans of a M orphological V iew of the World), Droemersche Verlagsanstalt, Zürich, 1966.

19. Draaijer, D.J., "Market orientedness of improvement programmes in manufacturing: results from field study research", International lournal of Operations \& Production Management, Vol. 12 No. 7/8, 1992, pp. 24-40.

20. Wilson, J., Thinking with Concepts, Cambridge University Press, Cambridge, 1966.

21. Bessant, J. and Grunt, M., Management and $M$ anufacturing Innovation in the United $\mathrm{K}$ ingdom and West Germany, Gower, A Idershot, 1985.

22. Ferdows, K. and De Meyer, A ., "Lasting improvements in manufacturing performance: in search of a new theory", lournal of Operations Management, Vol. 9 No. 2, 1990, pp. 168-84. Technology and Organization, University of Twente, Enschede, The Netherlands. 
This article has been cited by:

1. CoughlanPaul, Paul Coughlan, DraaijerDomien, Domien Draaijer, GodsellJanet, Janet Godsell, BoerHarry, Harry Boer. 2016. Operations and supply chain management. International Journal of Operations \& Production Management 36:12, 1673-1695. [Abstract] [Full Text] [PDF]

2. Alex Hill, Steve Brown. 2007. Strategic profiling. International Journal of Operations \& Production Management 27:12, 1333-1361. [Abstract] [Full Text] [PDF]

3. C. Martínez-Olvera, D. Shunk. 2006. Comprehensive framework for the development of a supply chain strategy. International Journal of Production Research 44:21, 4511-4528. [Crossref]

4. Kristina Säfsten, Mats Winroth. 2002. Analysis of the congruence between manufacturing strategy and production system in SMME. Computers in Industry 49:1, 91-106. [Crossref]

5. David Tranfield, Stuart Smith. 2002. Organisation designs for teamworking. International Journal of Operations \& Production Management 22:5, 471-491. [Abstract] [Full Text] [PDF]

6. Frans A.J. Ruffini, Harry Boer, Maarten J. van Riemsdijk. 2000. Organisation design in operations management. International Journal of Operations \& Production Management 20:7, 860-879. [Abstract] [Full Text] [PDF]

7. Stuart Orr. 1999. The role of technology in manufacturing strategy: experiences from the Australian wine industry. Integrated Manufacturing Systems 10:1, 45-55. [Abstract] [Full Text] [PDF] 